\author{
Łukasz Wróbel (iD https://orcid.org/0000-0003-3284-9298 \\ Uniwersytet Warszawski \\ l.wrobel@uw.edu.pl
}

\title{
Między osobą a wyglądem. O biografii Romana Witolda Ingardena
}

\section{Between the Person and the Appearance: On the Biography of Roman Witold Ingarden}

Abstract: The article is a commentary on Radosław Kuliniak's and Mariusz Pandura’s biography

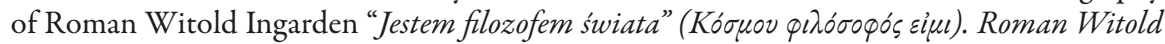
Ingarden (1893-1970). Having edited and published together a number of archival materials related to the history of Polish pre- and post-war philosophy as well, the authors have brought out a book on life and philosophy that is strongly corroborated by the archival materials. They have employed the positivist model of biography that implies particular (biological, historical) determinisms along with traditionally linear and sequential view of the past, the model based on substantial concept of the subject that can be isolated from its discursive or institutional networks of relations. In the article I discuss whether the positivist model of biographical writing along with the style and rhetoric employed in the book serve to achieve the goals set by the authors. Could the phenomenologist's biography be based on different conceptual and genological solutions? Can they be found among the notions and conceptions extracted from Ingarden's writings?

Keywords: Roman Witold Ingarden, biography, Radosław Kuliniak, Mariusz Pandura, phenomenology

Streszczenie: Artykuł jest komentarzem do biografii Romana W. Ingardena napisanej przez Radosława Kuliniaka i Mariusza Pandurę zatytułowanej "Jestem filozofem świata” (Kóoruv qı óooøós siuı). Roman Witold Ingarden (1893-1970). Opracowawszy i wydawszy również pokaźną liczbę materiałów archiwalnych dotyczących przed-i powojennej historii polskiej filozofii, autorzy opublikowali, opatrzoną licznymi potwierdzeniami archiwalnymi, książkę spod znaku życia i filozofii. Zastosowali w niej pozytywistyczny model biografii, implikujący określone (biologiczne, historyczne) determinizmy oraz tradycyjnie linearny i sekwencyjny obraz przeszłości, model oparty na substancjalnie ujmowanym podmiocie, wyodrębnialnym z sieci zależności dyskursywnych, instytucjonalnych. W artykule rozważam, czy pozytywistyczny model pisarstwa biograficznego, wraz z zastosowanymi w książce stylem i retoryką, pozwala autorom zrealizować założone przez nich cele. Czy biografia fenomenologa mogła być oparta na innych rozwiązaniach pojęciowych i genologicznych? Czy można takie odnaleźć pośród pojęć i koncepcji czerpanych z pism Ingardena? Słowa kluczowe: Roman Witold Ingarden, biografia, Radosław Kuliniak, Mariusz Pandura, fenomenologia 
Pięćdziesiąt lat - tyle czasu minęło w 2020 roku od śmierci Romana Ingardena. Tyle też trzeba było czekać na biografię filozofa ${ }^{1}$. Właściwie nie tylko na biografię. Dopiero od niedawna ukazują się publikacje będące rezultatem kwerend archiwalnych związanych z osobą fenomenologa: o charakterze biograficzno-historycznym $^{2}$, edycji listów ${ }^{3}$, protokołów posiedzeń seminaryjnych ${ }^{4}$, zapisów wykładów ${ }^{5}$, zbiorów fotografii ${ }^{6}$, wspomnień ${ }^{7}$, nie wymieniając okolicznościowych, w tym jubileuszowych, tomów poświęconych jego myśli ${ }^{8}$. Jak dotychczas nie ogłoszono drukiem twórczości diarystycznej ${ }^{9}$ oraz literackiej filozofa.

Obszerna, dwuczęściowa, licząca w sumie ponad tysiąc siedemset stron, wa-

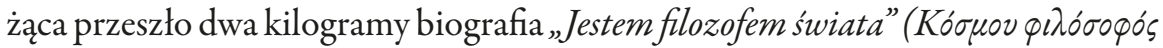
siul). Roman Witold Ingarden (1893-1970) to owoc tytanicznej pracy archiwalnej Radosława Kuliniaka i Mariusza Pandury. Tomy zostały opatrzone drobiazgowymi przypisami, wyposażone w gruntowną bibliografię (obejmującą publikacje filozofa, materiały archiwalne, źródła drukowane, literaturę przedmiotową

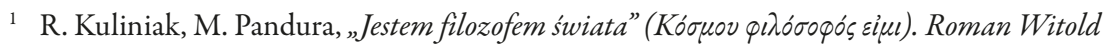
Ingarden (1893-1970). Część pierwsza: lata 1893-1938, Kęty 2019; tychże, „Jestem filozofem

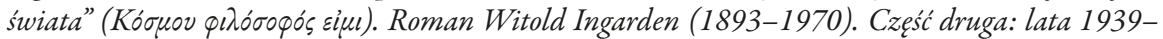
1970, Kęty 2020.

2 R. Kuliniak, M. Pandura, Roman Witold Ingarden we Wroctawiu. Zapomniana historia Uniwersytetu Wroctawskiego z 1945 roku, Kęty 2020; „Ruch Filozoficzny” 2020, t. LXXVI, nr 1: W pięćdziesiąta rocznice śmierci Profesora Romana Witolda Ingardena. Tutaj należy również wymienić publikację poświęconą instytucjonalno-politycznym dziejom filozofii polskiej (Ingarden jest jednym z jej bohaterów); ukazały się jej dwie części, trzecia jest w zapowiedziach wydawniczych: R. Kuliniak, M. Pandura, Ł. Ratajczak, Filozofia po ciemnej stronie mocy, cz. 1-2, Kęty 2018-2019.

3 Korespondencja Romana Witolda Ingardena z Kazimierzem Twardowskim, oprac., red. R. Kuliniak, D. Leszczyna, M. Pandura, Kęty 2016; Korespondencja Romana Witolda Ingardena. Z dziejów „Studia Philosophica. Commentarii Societatis Philosophicae Polonorum”, oprac., red. R. Kuliniak, D. Leszczyna, M. Pandura, Ł. Ratajczak, Kęty 2018; Korespondencja Izydory Dąmbskiej z Romanem Witoldem Ingardenem, oprac., red. R. Kuliniak, D. Leszczyna, M. Pandura, E. Ratajczak, Kęty 2018; Korespondencja Romana Witolda Ingardena z Wtadystawem Tatarkiewiczem; oprac., red., wstęp, wprowadzenie R. Kuliniak, M. Pandura, Kęty 2021.

${ }_{4}$ Lwowskie czwartki Romana W. Ingardena 1934-1937. W kregu problemów estetyki ifilozofii literatury, oprac. D. Ulicka, Warszawa 2020; R. Kuliniak, M. Pandura, Lwowskie Seminarium Arystotelesowskie Romana Witolda Ingardena z lat 1937-1938, Kęty 2020.

5 R. Ingarden, Lwowskie wyktady o „Krytycyzmie Kanta” z roku akademickiego 1935/1936, oprac., red. R. Kuliniak, M. Pandura, Kęty 2021.

6 Roman Ingarden. Filozof i fotograf/ Philosopher and Photographer, red. M.A. Potocka, Kraków 2020.

Spotkania. Roman Ingarden we wspomnieniach, red. L. Sosnowski, Kraków 2020.

8 Na przykład: Doświadczanie świata. Eseje o myśli Romana Ingardena, red. T. Maślanka, Warszawa 2020; Roman Ingarden and His Times, red. D. Czakon, A. Michna, L. Sosnowski, Kraków 2020.

9 Zob. R. Kuliniak, M. Pandura, Poeta sam na sam z soba - dziennik osobisty Romana Witolda Ingardena, „Konteksty Kultury” 2021, t. 18, z. 1, s. 149-159; R.W. Ingarden, Dziennik osobisty (wybór), oprac. R. Kuliniak, M. Pandura, „Konteksty Kultury” 2021, t. 18, z. 1, s. $160-166$. 
i literaturę pomocniczą), spisy prowadzonych zajęć na uniwersytetach Jana Kazimierza we Lwowie oraz Jagiellońskim w Krakowie, kalendarium życia, spis zawartości archiwum, które było w posiadaniu Romana Stanisława Ingardena, wybór fotografii ${ }^{10}$ oraz indeks osobowy.

Trzeba przyznać, że żaden z polskich filozofów, estetyków czy literaturoznawców nie doczekał się tak rozbudowanej biografii. Kuliniak i Pandura dotarli do olbrzymich zbiorów archiwalnych, odkryli mnóstwo materiałów źródłowych całość jest szczegółowa i pieczołowicie udokumentowana ${ }^{11}$.Z publikacji zwartych dotychczas dysponowaliśmy jedynie niewielkimi rozmiarowo szkicami biograficznymi Marii Gołaszewskiej i Zofii Majewskiej oraz wspomnieniami Romana Stanisława Ingardena poświęconymi kilkuletniemu toruńskiemu epizodowi życia fenomenologa $a^{12}$ - żadna z nich nie była tak osadzona w archiwach ani tak bogata w informacje. Kontekstem dla biografii pozostają oczywiście sukcesywnie opracowywane i wydawane materiały archiwalne bardziej lub mniej bezpośrednio związane z Ingardenem (część została wymieniona powyżej, ale nie można zapominać o edycjach korespondencji i zapisów wykładów Kazimierza Twardowskiego ${ }^{13} \mathrm{czy}$ dzienników Władysława Tatarkiewicza $\left.{ }^{14}\right)$.

Roman Ingarden w artykule Cztowiek i czas pisał: „Czymże jestem ja (...) człowiek działający? (...) jestem siłą, która sama siebie mnoży, sama siebie buduje i sama siebie przerasta (...). Jestem siłą, która się chce utrwalić - w sobie, w swym dziele, we wszystkim, z czym się spotyka"15. Te między innymi refleksje były punktem odniesienia dla - pomieszczonych w pierwszym tomie Sporu o istnienie świata - analiz czasowego sposobu istnienia zdarzeń i procesów. Filozof, rozważając różnicę między tym, co przeszłe, a tym, co teraźniejsze, pisał, iż można ją pomyśleć w taki sposób, że czas nie jest już mocą, która absolutnie

10 Spośród nich dwie fotografie zawarte w tomie pierwszym (fot. 34, 44) zostały też zamieszczone w tomie drugim (fot. 1, 15).

11 W Przedmowie do drugiego tomu biografii autorzy piszą: „Kwerendy te pokazały, że materiały archiwalne Ingardena są rozproszone, a w znacznej części nie zostały dotąd uporządkowane. Sprawę tę opiszemy osobno w przygotowywanym przez nas Przewodniku po archiwaliach Romana Witolda Ingardena". R. Kuliniak, M. Pandura, Przedmowa [w:] tychże, "Jestem filozofem świata"..., dz. cyt., cz. 2, s. 7.

12 M. Gołaszewska, Roman Ingarden. Cztowiek i dzieto, Kraków 1993; Z. Majewska, Ksiażeczka o Ingardenie. Szkic biograficzny, Lublin 1995; R.S. Ingarden, Roman Witold Ingarden. Życie filozofa w okresie toruńskim (1921-1926), Toruń 2000. Monografii Bogdana Ogrodnika (Ingarden, Warszawa 2000) w tekście głównym nie wymieniam z tego względu, że jej część biograficzna to zaledwie kilkanaście stron.

13 Korespondencja Wincentego Lutostawskiego z Kazimierzem Twardowskim. Lata 1893-1936, oprac., red. R. Kuliniak, D. Leszczyna, M. Pandura, Ł. Ratajczak, Kęty 2017; Korespondencja Wtadystawa Weryhy z Kazimierzem Twardowskim, oprac., red. R. Kuliniak, D. Leszczyna, M. Pandura, Ł. Ratajczak, Kęty 2017; K. Twardowski, Lwowskie wyktady akademickie, t. 1-2, oprac., red. R. Kuliniak, D. Leszczyna, M. Pandura, Ł. Ratajczak, Kęty 2018-2020.

14 W. Tatarkiewicz, Dzienniki. Tom 1. Lata 1944-1960, oprac. R. Kuliniak, D. Leszczyna, M. Pandura, Ł. Ratajczak, red. M. Urbańska-Bożek, Kęty 2019.

15 R. Ingarden, Cztowiek i czas [w:] tegoż, Książeczka o cztowieku, Kraków 1987, s. 68. 
niszczy byt, a to, co przeszłe, nie przestaje istnieć bezwzględnie ${ }^{16}$. Przeszłe zdarzenia i procesy pośrednio, poprzez swoje następstwa, uruchomione łańcuchy przyczyn i skutków, wyłaniają nowy byt, na przykład teraźniejszy stan świata. Ale to, co przeszłe, może też odzyskać swego rodzaju aktualność dzięki pracy pamięci. „Przypomnienie pośredniczy (...) między samym tym, co przeszłe, a nową teraźniejszością, do której jako coś aktualnego należy też samo przypomnienie (przypominanie sobie). Przypomnienie reaktualizuje do pewnego stopnia to, co przeszłe" ${ }^{17}$. Przeszłość istnieje realnie (nie czysto intencjonalnie), można odnaleźć jej ślady - rozsiane po teraźniejszości, acz zanikające w miarę upływu cza$\mathrm{su}^{18}$. Nie jest wytworem operacji świadomościowych, zachowuje ontologiczną niezależność od nich. Ponownie obdarzyć ją swego rodzaju zapośredniczoną aktualnością, czyli mocą oddziaływania, może, niekiedy nawet powinien, właśnie mechanizm i gest przypomnienia. Umiejętność pamiętania jest bowiem jedną z podstaw etycznego rozwoju człowieka ${ }^{19}$.

Twórcy „Jestem filozofem świata”... zdają się kierować pobudkami wpisującymi się w powyższe rozpoznania. „Dlaczego Roman Witold Ingarden, będąc światowym fenomenologiem, nie jest doceniany wśród polskich myślicieli ?"20 pyta w pierwszych słowach swojego wprowadzenia Radosław Kuliniak. W Przedmowie do drugiego tomu obaj autorzy zaznaczają z kolei, że biografia, jak i inne przygotowane przez nich publikacje, stanowią hołd złożony filozofowi w pięćdziesiątą rocznicę jego śmierci, zarazem zaś są pierwszymi efektami działalności Centrum Badawczego Ingarden (jednostka powołana na Uniwersytecie Wrocławskim w lipcu 2020 roku). Etyczny gest upamiętnienia, złożenia hołdu, idzie tutaj w parze z inicjatywą zbierania śladów, której aspekty archiwistyczny, edytorski, deskryptywny i poznawczy łączą się z reaktualizacją tego, co przeszłe, rozumianą jako konsekwentne przyczynianie się do wywierania wpływu na teraźniejszość, do wyłonienia nowego.

Całość została podzielona na dwie części: pierwsza obejmuje lata 18931938, druga - 1939-1970. Tom pierwszy spina klamra narodzin przyszłego

16 Tenże, Spór o istnienie świata, t. 1, przygotowała i partie tekstu przetłumaczyła D. Gierulanka, Warszawa 1987, §28, s. 190-191 [oraz] \$29, s. 198 i nast.

17 Dalej filozof pisał: „W przypomnieniu dokonuje się niejako próba wydobycia tego, co przeszłe, z przeszłości i zbliżenia go do nowej teraźniejszości”, to, co przypomniane, „uzyskuje aktywność, a tym samym i pewne określone oddziaływanie na to, co się rozgrywa w teraźniejszości”. Tenże, Spór..., dz. cyt., t. 1, §29, s. 200-201.

18 Wraz z upływem czasu „osłabia się (...) nośność istnienia tego, co przeszłe. Stopniowo tym bardziej i tym głębiej tonie ono w bezdennej głębi »zamarłej « przeszłości, im mniej »śladów « przeszłości jest w teraźniejszości”. Tamże, s. 202.

19 R. Ingarden, Lekceważenie pamięci, „Muzeum. Czasopismo Pedagogiczne, Poświęcone Sprawom Wychowania, Nauczania i Organizacji Szkolnictwa” 1938, R. LIII, z. 1, s. 8-18. Por. B. Garlej, Poetyka Ingardenowskich wspomnień hotdów oddawanych (nie tylko) fenomenologom, „Napis" 2019, seria XXV, s. 140-141.

20 R. Kuliniak, Spiritus movens [w:] R. Kuliniak, M. Pandura, „Jestem filozofem świata”..., dz. cyt., cz. 1, s. 7 . 
fenomenologa (1893) oraz śmierci w roku 1938 obu jego nauczycieli: Kazimierza Twardowskiego i Edmunda Husserla. Kontakty z obydwoma uczonymi wyznaczają zresztą zasadnicze osie przedwojennego rozwoju naukowego Ingardena (relacje z pierwszym pozwala w pewnej mierze śledzić z innej perspektywy opublikowana osobno korespondencja Romana Witolda z Twardowskim). Poza najbliższymi (krewnymi i żoną), Husserlem i Twardowskim, drugoplanowymi bohaterami tej części są też Edith Stein, Kazimierz Ajdukiewicz, Władysław Witwicki oraz Izydora Dąmbska, ale siłą rzeczy na scenie pojawiają się również Martin Heidegger, Stanisław Ignacy Witkiewicz czy Tadeusz Kotarbiński. Uwagę czytelnika mogą zwrócić przytoczony in extenso wiersz filozofa Mitość, pochodzący z 1914 roku, rozbudowane informacje dotyczące rigorosum Ingardena i Stein oraz nieznanych wcześniej perypetii fenomenologa związanych ze staraniami o habilitację (cenne są wypisy z dokumentów: wniosków, opinii, pisanych w ramach wspomnianych postępowań akademickich). Podstawą do stworzenia tej części były zasoby archiwów, opublikowane materiały źródłowe, a także zachowana korespondencja.

Tom drugi otwiera rzut oka na filozoficzny krajobraz Lwowa po odejściu na emeryturę (wkrótce zaś zgonie) Twardowskiego i Mścisława Wartenberga, kiedy na polu uniwersyteckim pozostali dwaj rywale: Ingarden oraz Ajdukiewicz; ostatnie strony to śmierć i pogrzeb Romana Witolda oraz przypomnienie ukazujących się jeszcze na początku lat siedemdziesiątych XX wieku jego publikacji. Powojenne losy filozofa powiązane są najważniejszymi nićmi z postaciami Ajdukiewicza, Dąmbskiej, Danuty Gierulanki, Kotarbińskiego, małżeństwa Krońskich, Adama Schaffa, Władysława Tatarkiewicza. Ciekawostką jest odpomniany i zrekonstruowany epizod wrocławski, który zresztą został szerzej opracowany w osobnej monografii ${ }^{21}$, również informacje odsłaniające kulisy starań o powołanie do istnienia Biblioteki Klasyków Filozofii oraz odbytych, po przejściu na emeryturę, naukowych podróży fenomenologa między innymi do Wielkiej Brytanii, Norwegii i Stanów Zjednoczonych. Ta część biografii oparta została przede wszystkim na archiwalnych i opublikowanych zbiorach listów, ale także na innych materiałach źródłowych (wnioskach, deklaracjach, umowach, sprawozdaniach, notatkach).

Zaletą obu tomów są liczne i obszerne cytaty z korespondencji, wniosków, sprawozdań, opinii na temat fenomenologa: naukowych (pióra Twardowskiego) czy politycznych, pisanych po wojnie przez tak zwane czynniki partyjne ${ }^{22}$; celny jest ich dobór (przednie są na przykład wypisy z listów Władysława Witwickiego do Ingardena).

21 R. Kuliniak, M. Pandura, Roman Witold Ingarden we Wroctawiu..., dz. cyt.

22 Dla przykładu charakterystyka napisana między grudniem 1949 roku a majem 1951 przez I sekretarza POP PZPR przy Uniwersytecie Jagiellońskim: „Zdecydowany idealista i wróg materializmu. (...) O nauce radzieckiej wyraża się z nieukrywaną zupełnie ironią. (...) Przy sobie gromadzi najbardziej reakcyjne, klerykalne elementy uczelni, które są pod zupełnym jego wpływem. (...) Prof. Ingarden Roman to zdecydowany, świadomy wróg, któremu należy odebrać katedrę". R. Kuliniak, M. Pandura, „Jestem filozofem..., dz. cyt., cz. 2, s. 324. 
Nikt zapewne w Polsce i poza jej granicami nie ma lepszego rozeznania w archiwach Ingardenowskich aniżeli Kuliniak i Pandura, nie sądzę, by ktokolwiek wiedział więcej o życiu autora Sporu o istnienie świata. Trudno zweryfikować sposób wykorzystania i opracowania materiałów, którymi dysponowali, niewątpliwie podziw i szacunek budzi natomiast obwarowanie biografii archiwalnymi poświadczeniami. Za „Jestem filozofem... kryje się wielka archiwistyczna robota. Gorzej, niestety, sprawy mają się ze stylem i retoryką tej książki. Warto jednak, by poniższe uwagi krytyczne nie przesłoniły jej znaczenia.

\section{"Mnogość w pewien sposób uporządkowanych wyglądów"}

Kuliniak i Pandura przejęli pozytywistyczny model biografistyki z wszelakimi implikowanymi przez niego determinizmami. Spinająca całość (ale i poszczególne tomy) klamra narodziny-śmierć wyznacza porządek tradycyjnej narracji biograficznej „od początku do końca”23. Jej sekwencyjność odtwarza chronologiczną linearność procesów biologicznych i historycznych, tak jakby obraz przeszłości nie był wynajdywany aktualnie, dzisiaj - w przygodnych ramach uwarunkowań językowych i instytucjonalnych, jak gdyby nie trzeba było, przynajmniej w kontekście fenomenologii, uwzględniać rozmaitych odmian czasu fenomenalnego (takich jak czas prywatny, czas intersubiektywny określonej społeczności czy czas mierzony zegarami ${ }^{24}$ ) oraz stosowanych w rekonstrukcji przez Ingardena tak zwanych skrótów perspektywicznych. Oczywiście, większość publikowanych biografii wpisuje się w tę tradycję, niemniej kwestia zastosowanego modelu żywotopisarstwa nie powinna, w moim odczuciu, być przezroczysta.

Zżalem nie odnotowuję $\mathrm{w}$ „Jestem filozofem... rozpoznania albo chociaż problematyzacji statusu poznania biograficznego w fenomenologii czy przynajmniej $\mathrm{w}$ fenomenologii Ingardena. Czy naprawdę zdani jesteśmy jedynie na XIX-wieczne wzorce operujące, wyodrębnialnym z sieci zależności językowych, instytucjonalnych, substancjalnie rozumianym podmiotem poddającym się uprzedmiotowiającym gestom biografisty 25 ? Biorąc pod uwagę znaczenie, jakie dla Husserla miał wybór właściwego punktu wyjścia, początkowego momentu namysłu, pamiętając też ostrożność Herberta Spiegelberga, z jaką otwierał swoje historyczne

23 Por. D. Ulicka, Stowa i ludzie. 10 szkiców z antropologii filologicznej, Warszawa 2013, s. 16-17.

24 R. Ingarden, Opoznawaniu dzieta literackiego, thum. D. Gierulanka, Warszawa 1976, \$17, s. $105-106$.

25 W ostatnim czasie Tomasz Bilczewski dobitnie pokazał, że opowieści spod znaku „życia i twórczości" w polskim literaturoznawstwie nieprzerwanie od pozytywizmu stanowią podnoszony i niejednokrotnie ciekawie rozwiązywany problem. Tenże, Subiekt - obiekt - abiekt: „pajęczo wiotka tkanina [w:] Wiek teorii. Sto lat nowoczesnego literaturoznawstwa polskiego, red. D. Ulicka, Warszawa 2000, s. 161-229. 
wprowadzenie do prezentacji ruchu fenomenologicznego ${ }^{26}$, mam wątpliwości, czy narodziny człowieka to właściwy początek biografii fenomenologa. Skoro fenomenologia wykrywa i opisuje prawa, czy w ogóle możliwa jest fenomenologiczna biografia jednostki, osoby? W przedostatnim zdaniu drugiego tomu czytam: „Ingarden aż po sam kres był wierny swojej dewizie: Primum philosophari, deinde vivere" 27 . Co znaczy „filozofować”, „żyć” w kontekście życia filozofa, ale też w odniesieniu do tego konkretnego fenomenologa i jego działalności naukowej? Co znaczy: „najpierw filozofować, potem żyć”? Czy ta dystynkcja jest w ogóle do utrzymania? Gdzie znajdują się punkty styku albo lepiej - zacięcia tych dwóch rejestrów? Z wykorzystaniem jak rozumianych pojęć życia, osobowości twórczej, twórczości naukowej, filozofii (krótko: na jakich podstawach filozoficznych, metodologicznych) zachodziły procesy konkretyzacji pomiędzy odczytywanymi przez autorów materiałami archiwalnymi a przedstawieniem dokonanym na kartach biografii ${ }^{28}$ ? Nie znajduję w książce Kuliniaka i Pandury śladów po rozpoznaniu i uwzględnieniu tych problemów. Na pewno niewypracowana została relacja między różnorakimi możliwościami archiwalnej rekonstrukcji a regułami budowania biograficznej narracji, między badaniami historycznymi a strukturą opowieści wpisującej się w tradycję dokumentalistyki życia i twórczości.

„Prace filozofa wyrastają z jego życia. Pisząc biografię, pragnęliśmy pokazać dzieje jego życia i filozofii, trwale zakorzenionej w myśli fenomenologicznej", pisze Radosław Kuliniak ${ }^{29}$. Ten cel nie w pełni został osiągnięty. Dzieje życia Ingardena są opisane, na kartach obu tomów odnotowano też jego kolejne publikacje, ale (pomijając znane komentarze fenomenologa do okoliczności powstawania Sporu o istnienie świata) właściwie zastosowany w cytacie spójnik odsyła tylko do równoległości życia i filozofowania. Autorzy biografii podają, gdzie ich bohater był, z kim rozmawiał i nad czym wtedy pracował, w moim jednak odczuciu przyległość przestrzenna i czasowa nie oznacza jeszcze wyrastania prac filozoficznych z życia, chyba że rozumieć jego momenty zaledwie jako jednostki kalendarium bądź swego rodzaju pudełka zawierające daty spotkań, wyjazdów czy publikacji, to znaczy na poziomie powierzchni. Z dwóch możliwych (i niewykluczających się) dominant: fakty biograficzne - fakty dyskursywne, $\mathrm{w}$ „Jestem filozofem... punkt ciężkości spoczywa jednoznacznie na pierwszej.

Narracja niekonwencjonalna być może pozwoliłaby uwzględnić Ingardenowskie ujęcia na przykład cielesnej przedmiotowości człowieka, podmiotowości twórczej czy związków przyczynowych, a także krytycznie ustosunkować się do najbardziej uschematyzowanych ujęć i przedstawień (właściwie mitów):

26 H. Spiegelberg [wspólpraca K. Schumann], The Phenomenological Movement: A Historical Introduction, The Hague 1982, s. 1-6.

27 R. Kuliniak, M. Pandura, „Jestem filozofem..., dz. cyt., cz. 2, s. 699.

28 Podobne pytania, acz w odmiennym kontekście lekturowym, zadawał Ingarden w recenzji rozprawy Stefana Baleya Osobowość twórcza Żeromskiego pomieszczonej w: „Nowa Książka” 1938, nr 5, s. 16.

29 R. Kuliniak, dz. cyt., cz. 1, s. 9. 
Husserla, Twardowskiego, Ingardena czy Tatarkiewicza; fenomenologii, przedwojennego środowiska lwowskiego, Szkoły Lwowsko-Warszawskiej jako ruchów, szkół filozoficznych czy swego rodzaju formacji intelektualnych - umożliwiłaby uniknięcie ryzyka prezentyzmu. Autorzy "Jestem filozofem..., przedstawiając osoby i grupy środowiskowe takimi, jaki ich wizerunek explicite wyłania się z materiałów źródłowych, wpadli jednak w pułapkę totalizującej narracji operującej schematycznymi uproszczeniami.

„Chcieliśmy spojrzeć na życie oraz dzieło Ingardena z jego perspektywy" ${ }^{30}$ w sposobie realizacji tej decyzji kryje się jedno ze źródeł ułomności omawianej biografii. Autorzy podążają za samointerpretacjami Ingardena, również wyrażanymi przezeń emocjami, najczęściej bez krytycznego dystansu, co owocuje brakiem niezbędnych rozgraniczeń na linii ja tekstowe-ja empiryczne.

\section{„wierne odwzorowania rzeczywistości”31}

Gdy Ingarden poruszał w $O$ dziele literackim zagadnienie reprezentowania (to jest przedstawiania) życia lub rzeczywistości w historycznym dziele naukowym, pisał, że „czysto intencjonalne przedmioty są w swej zawartości dostosowane do odpowiednich przedmiotów rzeczywistych i są z nimi utożsamiane"32. Jaki Ingarden wyłania się zza konkretyzacji dokonanych przez Kuliniaka i Pandurę? Jaka jest jego charakterystyka?

Pozytywistyczny z ducha, biograficzny prezentyzm wraz z decyzją pisania „z punktu widzenia Ingardena” przyniosły rezultat w postaci uschematyzowanego obrazu filozofa, wizerunku nazbyt często zbliżającego się do retoryki parenetycznej. Poniżej kilka z wielu podobnych fragmentów:

Nigdy nie wybiegał niepotrzebnie przed szereg, lecz zawsze starał się mieć własne zdanie. Wypowiadał się tam, gdzie był na to czas i miejsce ${ }^{33}$.

Nosił w sobie niespotykaną mądrość, która rozlewała się na najbliższe otoczenie, zwłaszcza w momencie, gdy zaczynał mówić o fenomenologii. Słowo płynęto i ujmowało zasięgiem wszystko, co znajdowało się na horyzoncie. Ingardena zawsze miło było słuchać, lecz równie miło było uczyć się od niego życia i filozofii. (...) Nie lubił krętactwa i obłudy. Mógł się spierać, lecz gdy widział, że adwersarz

30 Tamże, s. 9.

31 Fragment uwag poświęconych poznawaniu dzieła naukowego: „Albo przedmioty przedstawione zostają uznane jako trafne, wierne odwzorowania rzeczywistości, albo w wyniku odwołania się do »doświadczenia « zostają odrzucone jako fikcja, resp. jako błąd”. R. Ingarden, $O$ poznawaniu..., dz. cyt., \$20, s. 147.

32 R. Ingarden, $O$ dziele literackim. Badania z pogranicza ontologii, teorii jezyka i filozofii literatury, tłum. M. Turowicz, Warszawa 1960, §37, s. 315.

33 R. Kuliniak, M. Pandura, „Jestem filozofem..., dz. cyt., cz. 1, s. 229. 
celowo prowokuje spór, to potrafił ustąpić i zrezygnować z największych zaszczytów oraz funkcji. Umiał cierpliwie czekać na swój czas ${ }^{34}$.

Miał Ingarden w sobie doskonale rozwinięty zmysł rozpoznawania wokół siebie ludzi dobrych i życzliwych. Nigdy nie odtrącał nikogo, kto chciał z nim współpracować i uczyć się pracy filozoficznej ${ }^{35}$.

Z pokorą jednak podchodził do własnych osiągnięć. Potrafił zachować dystans i wykazać się odpowiednią kindersztubą. (...) Nawet gdy filozof nie czuł się dobrze i był przeziębiony, a na dworze szalał siarczysty mróz i zawieja śnieżna, wartkim krokiem zmierzał na uniwersytet do swoich studentów. Nigdy nie zawiódł oddanych sprawie fenomenologicznej uczniów. Na horyzoncie tych zmagań Ingardena zawsze najważniejszy pozostawał człowiek, a dopiero później liczyły się idee. (...) Zawsze traktował swoją pracę poważnie i stawiał przed sobą najwyższe wymagania ${ }^{36}$.

Szczyt hagiograficznego nastawienia osiągnęli autorzy, kiedy rozdział poświęcony wojennym losom syna filozofa, Jerzego Kazimierza Ingardena, jego tużpowojennym problemom zdrowotnym oraz śmierci zatytułowali Hiob.

Ingarden, nawet jeżeli w swoich publikacjach rzadko epatował komicznym czy ironicznym dystansem, to raczej nie bywał wzniosły, patetyczny czy sentymentalny (pomijam paragrafy w $O$ dziele... poświęcone jakościom metafizycznym i niektóre eseje z Książeczki o cztowieku), nie sądzę, by zasłużył na opisanie w powyższy sposób. Jak się zdaje, nie był typem krotochwilnego wykładowcy, ale nie był też zupełnie pozbawionym poczucia humoru akademickim świętym fenomenologicznej nauki zgodnie z tym, jak wspominają go Maria Gołaszewska, Janina Makota, Andrzej Półtawski czy Krzysztof Zanussi ${ }^{37}$. Owszem, jego pisarstwo to filozofia profesorska, niezniżająca się do zagrywek retorycznych czy stylistycznych ornamentów. Ale też, by oddać mu sprawiedliwość, i nie wnikając w realia prowadzonych z Witkacym „rozmów istotnych”, potrafil przecież nieoczekiwanie analizować sytuacje alkoholowe („Czasem w patologicznych wypadkach przygasa retencja » np. w niewinnym zatruciu alkoholowym «"38), narkotykowe i erotycz$n \mathrm{e}^{39}$. Między retorycznymi pociągnięciami piórem, kreślącymi wizerunek dobrego, moralnego ${ }^{40}$ i poważnego filozofa, niczym Paweł Obarecki, brnącego przez

34 Tamże, s. 358-359.

35 Tamże, s. 500.

36 R. Kuliniak, M. Pandura, ,Jestem filozofem..., dz. cyt., cz. 2, s. 14 [i] 17.

37 Spotkania..., dz. cyt., s. 164, 221, 239, 356.

38 R. Ingarden, Spór o istnienie świata, t. 2, cz. 2, przygotowała i partie tekstu przetłumaczyta D. Gierulanka, Warszawa 1987, §77, s. 159 oraz $\$ 78$, s. 222.

39 Tamże, $\$ 78$, s. 203-204, 214 [przyp. 88], 222.

40 W odniesieniu do relacji z Edith Stein autorzy piszą: „Nie trzeba i nie wolno w relacjach Ingardena z panną Stein doszukiwać się czegoś, co zostało między nimi wytworzone z wielkim wysiłkiem w trudnych czasach wojny w Getyndze i Fryburgu. Istniała między nimi szczera 
śniegi, by spełnić swój obowiązek, nie odnajduję człowieka posługującego się przykładami Husserla, mówiącego we śnie po polsku ${ }^{41}$, wysypki skórnej (w kontekście wyglądów, w których dane są żywe cudze ciała, i w odniesieniu do warstwy wyglądów uschematyzowanych $\mathrm{w}$ dziele literackim ${ }^{42}$ ) czy percypującego podczas seminarium bachantkę ${ }^{43}$. Trudno mi w ogóle odnaleźć żywego człowieka. Nie tylko krytyk i historyk literatury, jak chciał Tadeusz Żeleński (Boy), ale także biograf powinni odbyć praktykę „odbrązowniczą”.

Uproszczona retoryka zaowocowała też uschematyzowanymi ujęciami postaci z otoczenia fenomenologa, na przykład Husserla i Heideggera. Znane są niemal mistyczna, quasi-religijna atmosfera panująca w środowisku uczniów Husserla ${ }^{44}$ oraz ich pełen czci stosunek do Mistrza. Opisywane były również charakter i postępowanie Heideggera. Autorzy „Jestem filozofem... piszą o obu $\mathrm{z}$ sugerowanej perspektywy Ingardena ${ }^{45}$, w tym wypadku jednak wręcz licytują się z nim na przymiotniki i ich stopniowanie. Twórcy fenomenologii wystawiają laurkę:

Pragnął jedynie uczyć myśleć. Największą radość sprawiało mu, gdy student sam przychodził do niego z własną propozycją. Jeszcze lepiej było, gdy wpisywała się ona w jego badania. Nie dzielił studentów na lepszych i gorszych, czy też na tych, którzy mieli większy staż. Cenił kreatywność myślenia i sprzyjał jej rozwojowi. Był przy tym doskonałym prowokatorem ${ }^{46}$.

O Husserlu - u którego boku, jak czytam, Ingarden w latach 1916-1917 cieszył się, że jest „jednym z niewielu wybrańców, którzy mogą nadal pić wodę ze zdroju fenomenologicznego" ${ }^{\text {"7 }}$ - Kuliniak i Pandura piszą z nazwiska bądź właśnie jako o „Mistrzu”, przejmując manierę uczniów fenomenologa. Ten wyidealizowany portret ma swoje przeciwieństwo w równie zestereotypizowanym konterfekcie Heideggera, którego przywarą było, że „chciał za wszelką cenę zaistnieć i stać się

i dojrzała przyjaźń, wzmocniona wsparciem naukowym”. R. Kuliniak, M. Pandura, „Jestem filozofem..., dz. cyt., cz. 1, s. 307.

${ }_{41}$ R. Ingarden, O jezzyku i jego roli w nauce [w:] tegoż, $Z$ teorii jezyka i filozoficznych podstaw logiki, Warszawa 1972, s. 60.

42 Tenże, $O$ dziele..., dz. cyt., $\$ 43$, s. 345.

43 Lwowskie czwartki..., dz. cyt., s. 131.

${ }_{44}$ Zob. H. Conrad-Martius, Moja przyjaciótka Edyta Stein, tłum. J. Zychowicz, „Znak. Idee” 1989, nr 1, s. 4; D.R. Sobota, Narodziny fenomenologii z duch a pytania. Johannes Daubert i fenomenologiczny rozruch, Warszawa 2017, s. 147-155.

45 „Wstał wcześnie rano, zbudzony odgłosami wszechobecnej za oknami wiosny. (...) Z wielką ufnością, zapatrzony w cud przebudzenia, udał się na kolejny z wykładów Husserla. To, co usłyszał wówczas, było dla niego długo wyczekiwanym objawieniem”. R. Kuliniak, M. Pandura, „Jestem filozofem..., dz. cyt., cz. 1, s. 136.

46 Tamże, s. 179.
47 Tamże, s. 224. 
filozofem wiodącym wśród akademików niemieckich”48. Piszą o nim jako o „małym kuglarzu z Messkirch” otaczającym się „nimbem mistycyzmu”"99; „filozofie o zmiennej twarzy, kameleonie"50, który tak zmącił atmosferę naukową we Fryburgu (w 1922 roku), że ta nie przyciągała Ingardena ${ }^{51}$; że roztoczył czar nad autorem Badań logicznych, a inni filozofowie niemieccy podążali za nim ślepo, ,jak za guru sekty”, zamiast korzystać „z tego, co daje im na co dzień i bezinteresownie Husserl”. Wreszcie nazywają go „nowo namaszczonym szwarcwaldzkim »królem « niemieckiej filozofii", do którego w 1927 roku przybył Ingarden, by w Marburgu „poznać jego emigracyjny dwór i obyczaje” ${ }^{52}$. Nazbyt to biało-czarna retoryka, jedynie powielająca mity i stereotypowe wizerunki ${ }^{53}$. Obejmuje ona również przeciwstawne charakterystyki Heideggera oraz Ingardena. O ile pierwszy dążył do zawłaszczenia kontaktów z autorem Idei..., jego działalność miała zaś na celu własną sławę, o tyle drugi: „Nie pragnął rozgłosu, lecz wiedzy, której umiłowanie zaszczepił mu właśnie nie kto inny, jak Husserl”’54.

Brak krytycznego dystansu do materiałów źródłowych objawia się również w opisach relacji polskiego fenomenologa z Twardowskim. Bez względu na liczbę kłód rzucanych przez tego ostatniego pod nogi starającemu się o habilitację Ingardenowi, niezależnie też od cech osobistych Twardowskiego (i Ajdukiewicza), z budowanym przez Kuliniaka i Pandurę obrazem skromnego ${ }^{55}$, cierpliwego, nigdy niewychodzącego przed szereg akademika kłóci się choćby wizerunek płynący z cytowanych listów Twardowskiego ${ }^{56}$. Nie poświadczają go (tj. explicite

\footnotetext{
48 Tamże, s. 225

49 Tamże, s. 226-227.

50 Tamże, s. 229.

51 Tamże, s. 367.
}

52 Tamże, s. 527. Dalszy ciąg tego fragmentu: „Po przybyciu na Uniwersytet Filipa szybko okazało się, że z Heideggerem było tak, jak w słynnej bajce Hansa Christiana Andersena Nowe szaty cesarza. Cóż z tego, że napisał przełomowe i wielkie dzieło [Sein und Zeit - Ł.W.], które na Niemcach zrobiło tak wielkie wrażenie, skoro prawie wcale o nim nie wspominał? W Marburgu okazało się, że Heidegger czasem napomknął o tym lub owym. To zaś miało wystarczyć zapatrzonym w niego jak w obrazek, studentom”. Tamże, s. 527-528.

53 Sam Ingarden lepiej pisze o Heideggerze (nawet w kąśliwych przypisach z tomów jego Dziet filozoficznych) aniżeli Kuliniak i Pandura patrzący z perspektywy swojego bohatera. A przecież gdy na przykład w $O$ dziele literackim pojawia się odwołanie do niemieckiego filozofa, Ingarden przytacza zaczerpnięte odeń wyrażenie „enthüllen” - „odsłonić”, by korzystać z niego w dalszych partiach rozprawy. R. Ingarden, $O$ dziele..., dz. cyt., $\$ 7$, s. 49.

54 R. Kuliniak, M. Pandura, „Jestem filozofem..., dz. cyt., cz. 1, s. 520.

55 „Można chyba powiedzieć, nawet na pewno, że był zadufany, chodził dumny”, wspomina Maria Gołaszewska. Spotkania..., dz. cyt., s. 166.

56 Por. „muszę przyznać, że od dawna mnie irytuje bezceremonialny sposób, w jaki się on przyłącza do mnie, gdy ja w czyimś towarzystwie wychodzę z uniwerku. Mam to przekonanie, że ja, widząc starszego człowieka idącego z kimś innym, nie przyłączyłbym się do niego bez jego poprzedniej, wyraźnej zachęty. A Ingarden postępuje tak, jak gdyby nie miało być wątpliwości, że jego towarzystwo zawsze musi być dla każdego pożądane”. R. Kuliniak, M. Pandura, „Jestem filozofem..., dz. cyt., cz. 1, s. 587. 
kreślonego wizerunku autora Sporu...) przywoływane sceny pretensji Ingardena o własny lokal, skłonność do manifestowania przezeń swojej profesorskiej pozycji $^{57}$ czy wyliczanie Tatarkiewiczowi liczby wierszy poświęconych w Historii filozofi jego dorobkowi w porównaniu z miejscem poświęconym Ajdukiewiczowi (trzydzieści dwa do trzydziestu ośmiu) ${ }^{58}$. Informacja stematyzowana w narracji Kuliniaka i Pandury nie zawsze pokrywa się z informacjami stematyzowanymi oraz implikowanymi w cytowanych przez nich materiałach.

\section{Narzędzie językowe}

W Ojezyku i jego roli w nauce Ingarden pisat:

Ad usum poznawania rzeczywistości (nauki) posługujemy się językiem szczególnie dobranym nie tylko w zasobie swoich słów, ale ukształtowanym tak, żeby posiadał struktury semantyczne potrzebne do odwzorowania rzeczywistości. Budowę języka służącego poznaniu stosuje się do postulatów stawianych przez poznanie ${ }^{59}$.

Ta dyrektywa nie w pełni znajduje realizację $\mathrm{w}$ „Jestem filozofem... Biograficzna opowieść Kuliniaka i Pandury oparta jest na ciągu mediacji między pojedynczością osoby a ogólnością (oraz, najwyraźniej, założoną prawdziwością) doxy, przy czym podstawowym zwornikiem tych mediacji jest mechanizm prozopopei, sugerujący wprawdzie jakąś figuratywność podmiotu, ale nazbyt często wydobywający raczej powszechną obowiązywalność prawd ogólnych. Tymi biografia jest wręcz naszpikowana. By wymienić tylko kilka, godnych umieszczenia w słowniku Flauberta, komunałów: „Dzieci do szkoły chodzić muszą, choć zazwyczaj nie lubią" ${ }^{60}$, „Młodość rządzi się szalonymi prawami” ${ }^{61}$, „Czegóż jednak nie zniesie się dla szczęścia ukochanego dziecka”"2 "W Wciąż wpadamy w dołki, które sami sobie kopiemy” ${ }^{63}$, „Nie samą jednak ciężką pracą żyje filozof. Czasem musi także odetchnąć świeżym powietrzem w doborowym towarzystwie" ${ }^{\prime 4}$. Zaskakuje wykorzystanie truizmów w biografii fenomenologa, który niejeden

57 Wskutek starań Ingardena, niedawno nominowanego profesora, o własny gabinet (także z powodu problemów lokalowych) Danielę Gromską trzeba było przenieść do pokoju Twardowskiego (który sam przenosił jej rzeczy), natomiast część zbiorów bibliotecznych na inne piętro. „Delikatnym tego człowieka nazwać trudno!”, kwitował Twardowski. Tamże, s. 654-656.

58 R. Kuliniak, M. Pandura, „Jestem filozofem..., dz. cyt., cz. 2, s. 298-301.

59 R. Ingarden, O jezzyku..., dz. cyt., s. 89.

60 To pierwsze zdanie rozdziału nota bene zatytułowanego Szkota zwykle bywa nudna. R. Kuliniak, M. Pandura, „Jestem filozofem..., dz. cyt., cz. 1, s. 62.

61 Tamże, s. 86-87.

62 Tamże, cz. 2, s. 284.

63 Tamże, s. 396.

64 Tamże, s. 415. 
akapit poświęcił analizom schematycznych słów, zdań i zespołów zdań oraz potrzebie odrzucania (i w literaturze, i w nauce) klisz językowych - zautomatyzowanych wyrazów ",ęzyka zwyrodniałego", utrudniających bądź wręcz uniemożliwiających poznanie ${ }^{65}$.

Należy podkreślić, że w obu tomach jest naprawdę niewiele literówek i blędów językowych, co już dawno przestało być regułą w polskojęzycznych publikacjach naukowych. Odnotowany w stopce redakcyjnej jako korektor Łukasz Front wykonał świetną robotę. Niestety, nie sprawdził się jako redaktor. Autorzy biografii zdradzają nadmierną predylekcję do komunałów, związków frazeologicznych oraz idealizowania za pomocą przymiotników i przysłówków odprzymiotnikowych. Jeżeli pojawia się kwestia marzeń o szczęściu w miłości, Kuliniak i Pandura piszą o wybrance serca tworzącej bezpieczną przystań wypełnioną gaworzeniem bobasów, ciepłymi opowieściami dziadków, zapachem pysznego obiadu i świeżej pościeli ${ }^{66}$. Jeżeli mowa o przyjaciołach, niechybnie pojawią się określenia „wierna towarzyszka wszelkich udręk i radości filozoficznych, powierniczka trosk i cierpień" (tu akurat uwaga o Edith Stein ${ }^{67}$. Rozmowom, wspominaniu, radościom i zachwytom obowiązkowo „nie ma końca” ${ }^{68}$. Spektakl mieszczańskiej egzystencji i sentymentalistyczna z ducha etyka przyjaźni.

Autorzy nie zawsze panują nad stosowanymi wyrażeniami frazeologicznymi, zdarza się, że niewłaściwie z nich korzystają. Przykładowo, gdy Ingarden rezygnuje w 1948 roku z redagowania reaktywowanego przez siebie pierwszego polskiego obcojęzycznego pisma filozoficznego, piszą: „Radość Schaffa i jego wspóttowarzyszy z tego, że »Studia Philosophica « wchodzą w okres schyłkowy swojej działalności, była nie do przecenienia" ${ }^{\circ}$.

W zasadzie od początku biografii czytelnik zderza się z drażniącym, najczęściej egzaltowanym stylem. Drugi akapit pierwszej części mówi o narodzinach Ingardena rok po śmierci ośmioletniej córki jego rodziców. Roman Witold był:

darem łez, bólu i zgryzoty. (...) nie sposób opisać w tym momencie bólu matki, który wyrywał się z jej wnętrza. Pocałunek śmierci przyniósł jednak promyk nadziei na lepsze jutro. Ciążą, oczekiwanie na nowe narodziny, a wreszcie poród i radosne kwilenie niemowlęcia uratowały wszystkich. Wydobyły rodzinę Ingardenów z padołu tez $z^{70}$.

65 Por. „nie możemy stosować gotowych sposobów określania i wiązania faktów. Gdy to robimy, staje między nami a rzeczywistością zapora (idola fori) i nie umiemy świeżo spojrzeć na rzeczy. Następuje skarlenie funkcji zdobywania doświadczenia”. R. Ingarden, O języku ..., dz. cyt., s. 113.

66 R. Kuliniak, M. Pandura, „Jestem filozofem..., dz. cyt., cz. 1, s. 176-177. Gdzie indziej znajduję zdanie o „pięknej i rozkwitającej jak tulipan na wiosnę dziewczynie”, tamże, s. 86.

67 Tamże, s. 257.

68 Tamże, cz. 1, s. 26, 696; cz. 2, s. 80, 143, 188, 298, 425, 549.

69 Tamże, cz. 2, s. 272.

70 Tamże, cz. 1, s. 20. 
To nie jedyny operujący taką stylistyką fragment. Na skali jakości niewątpliwie konkuruje natomiast z początkiem rozdziału zatytułowanego Toruńskie pierniki Ingardena:

Toruń kojarzy się przeważnie z Mikołajem Kopernikiem i piernikami. Nie znamy chyba nikogo, kto by nie lubił wypełnionych doskonałym jagodowym nadzieniem i polanych lukrem tamtejszych pierników. Smakują doskonale! Trzeba jednak wielu lat, aby dojść do wprawy w ich wypiekaniu. Podobnie było z Ingardenem. (...) Swoją karierę naukową (...) musiał więc „wygniatać” latami, jak masę piernikową ${ }^{71}$.

W tym wypadku, jak rozumiem, jednym z toruńskich pierników fenomenologa jest jego kariera naukowa.

Zastrzeżenia budzi też stylistyka tytułów rozdziałów, w których nadużywane są powtórzenia i parafrazy rozmaitych skrzydlatych słów, na przykład: $B o$ to się zwykle tak zaczyna; Pierwsze koty za ptoty; Jak pech, to pech!; Nie ma tego ztego, co by na dobre nie wyszto; Tylko we Lwowie!; Uwaga, uwaga, nadchodzi...; Non omnis moriar (ostatni to tytuł rozdziału traktującego o śmierci Ingardena). Rażą również tytuły pisane w pierwszej osobie (na przykład: Jestem zty znowu będę musiat pisać po niemiecku!; Jadę do Rzymu!; Teraz zobacze Paryż!) i układane w fabularne sekwencje: Idę na emeryturę; Jestem emerytem!; Co ja teraz będę robit? Część $\mathrm{z}$ nich to zapewne cytaty z listów samego Ingardena, nie są jednak oznaczone, domyślam się natomiast, że ich komizm jest mimowolny, niezamierzony.

\section{Pojednanie z rzeczywistością}

Georg Wilhelm Friedrich Hegel zanim napisał w przedmowie do Zasad filozofii prawa, że sowa Minerwy wylatuje dopiero z zapadającym zmierzchem, podkreślał, iż jest ona (filozofia) „swoją własną epoką ujętą w myślach” i jako rozumowe poznanie daje możliwość pojednania z rzeczywistością ${ }^{72}$. Czy filozofia jako świadomość swojego czasu koniecznie musi pozostawać w czasowym dystansie? W jakim stopniu jej wiedza jest dojrzałym objęciem całości, spojrzeniem po horyzont, ale u schyłku dnia, a w jakim stopniu może starać się in medias res odpowiadać na wymogi chwili? Fenomenologia Ingardena (jako metafizyczny realizm) zajmuje - chronologiczne, dyskursywne, środowiskowe - miejsce pomiędzy idealizmami neokantystów oraz Husserla i neopozytywizmem wiedeńczyków z jednej strony a egzystencjalizmem (na przykład w wersji Heideggera) z drugiej. Między transcendentalnymi i logicznymi analizami narzędzi poznawczych (mentalnych,

71 Tamże, s. 358.

72 G.W.F. Hegel, Zasady filozofii prawa, tłum. A. Landman, Warszawa 1969, s. 19-21. 
dyskursywnych) a faktycznością i osobową egzystencją. Dlaczego autorowi Sporu o istnienie świata nie udało się stworzyć własnej szkoły filozoficznej? Z czego wynika, że jego fenomenologia słabo funkcjonuje w polskim obiegu naukowym?

O przed-i powojennych próbach stworzenia przez Ingardena własnej szkoty Kuliniak i Pandura piszą kilkakrotnie. Jej zalążkami miały być lwowskie seminaria estetyczne i arystotelesowskie ${ }^{73}$, po 1945 roku krąg nowych wychowanków oraz uczestników krakowskich seminariów, a także działalność translatorsko-edytorska (BKF) postrzegana jako kontynuacja zadań i zobowiązań przedwojennego środowiska lwowskiego. I przed wojną, i po niej udawało się Ingardenowi zgromadzić fantastyczne kolegium. Jego rozwój naukowy postępował w ramach relacji mistrz (Twardowski, Husserl) - uczeń, zaś szczególność ruchu fenomenologicznego, którego był częścią, uwidacznia się w pracach wspólnych, grupowym wspól-myśleniu - miał więc gotowe wzorce. Co zatem nie zadziałało? Wszak reprezentowany przez polskiego filozofa realizm w obrębie fenomenologii, tak jak koncepcje innych uczniów Husserla, na powrót umieszczał świadomość (oraz ciało) w granicach świata realnego i w tym sensie mógł być odebrany jako analogiczna odpowiedź na potrzeby powojennej aktualności ${ }^{74}$.

Lwowskie seminaria Ingardena to lata trzydzieste, ale nie jest to już czas grup ześrodkowanych wokół „Mistrza”. Wszelkie kolektywy naukowe, koła filozoficzne oraz literaturoznawcze w czwartej dekadzie XX wieku obywają się bez jednoosobowego centrum. Z kolei lata sześćdziesiąte już w ogóle nie są czasem szkół, raczej nurtów, kierunków i ewentualnie stylów (myślowych, językowych) oraz jednostek swobodnie przekraczających tradycyjne granice fakultetów. To też okres, który przyniósł eksplozję nowych idiolektów i dykcji dyskursywnych.

W powojennej wersji O poznawaniu dzieta literackiego Ingarden pisat:

Ludzie, którzy np. razem dokonali dobrze przeprowadzonej analizy fenomenologicznej konkretnych zjawisk, wiedzą, jak można się w niezawodny sposób porozumieć nawet co do trudnych zjawiskowo sytuacji i dojść przy tym do utworzenia subtelnego wspólnego języka75.

73 O sentymencie Ingardena do lwowskich seminariów świadczą liczne komentarze w przypisach, które po latach umieszczał w tomach Dziet filozoficznych, powołując się na przedwojenne dyskusje, przypominając ich nieżyjących już uczestników.

74 Ingarden transcendentalny idealizm Husserla traktuje jako reakcję „Mistrza” na tragedie, których doświadczył podczas pierwszej wojny światowej: „»W takim świecie nie mógłbym żyć «powiedział nam Husserl podczas 70-lecia swych urodzin, wskazując na swą filozofię jako pewnego rodzaju ratunek przed złem świata. Realność tego świata, a tym samym niesłychany ucisk, pod którego presją żył i cierpiał przez szereg lat, usiłował jakby zrzucić z siebie, osłabiając niejako charakter jego istnienia i robiąc go jedynie intencjonalnym odpowiednikiem czystej świadomości". R. Ingarden, Przemówienie radiowe na stulecie urodzin E. Husserla, [brak tłum.] [w:] tegoż, Z badań nad filozofia wspótczesną, Warszawa 1963, s. 627-628.

75 R. Ingarden, O poznawaniu..., dz. cyt., s. 338. 
Tworzenie szkoły filozoficznej oznacza między innymi konieczność wypracowania wspólnego języka. Czy taki był jeszcze możliwy ${ }^{76}$ ? O niedostatecznej obecności koncepcji fenomenologa w polskim obiegu naukowym, tudzież o fiasku w powoływaniu przezeń do istnienia własnej szkoły, mogłabyż w drugiej połowie XX wieku przesądzić kwestia języka ${ }^{77}$ ?

Biografia "Jestem filozofem świata”... nie udziela przekonującej odpowiedzi na sformułowane przez jej twórców pytania. Autorów nie przybliżają do niej obrany model narracji biograficznej oraz stosowane styl i retoryka. Pozostaje w sferze niezaktualizowanych możliwości, że biografia korzystająca z rozpoznań fenomenologii pozwoliłaby na wydobycie i uwzględnienie odmiennych statusów ontologicznych osoby uczonego, jego tekstowego ja, szkoły, ruchu i środowiska, wraz z różnorakimi modusami czasowości, w jakich funkcjonują. Raczej we wzajemnych splotach tych zagadnień upatrywałbym warunków możliwości rozwiązania postawionych kwestii.

\section{Bibliografia}

Conrad-Martius H., Moja przyjaciótka Edyta Stein, tłum. J. Zychowicz, „Znak. Idee” 1989, nr 1.

Doświadczanie świata. Eseje o myśli Romana Ingardena, red. T. Maślanka, Warszawa 2020. Garlej B., Poetyka Ingardenowskich wspomnień hotdów oddawanych (nie tylko) fenomenologom, „Napis” 2019, seria XXV.

Gołaszewska M., Roman Ingarden. Cztowiek i dzieto, Kraków 1993.

Hegel G.W.F., Zasady filozofii prawa, tłum. A. Landman, Warszawa 1969.

Ingarden R., Książeczka o cztowieku, Kraków 1987.

Ingarden R., Lekceważenie pamięci, „Muzeum. Czasopismo Pedagogiczne, Poświęcone

Sprawom Wychowania, Nauczania i Organizacji Szkolnictwa" 1938, R. LIII, z. 1. Ingarden R., Lwowskie wyktady o,Krytycyzmie Kanta” z roku akademickiego 1935/1936, oprac., red. R. Kuliniak, M. Pandura, Kęty 2021.

Ingarden R., O dziele literackim. Badania z pogranicza ontologii, teorii jezyka i filozofii literatury, tłum. M. Turowicz, Warszawa 1960.

Ingarden R., O poznawaniu dzieta literackiego, tłum. D. Gierulanka, Warszawa 1976. Ingarden R., [rec.: S. Baley, Osobowość twórcza Żeromskiego, Warszawa 1936], „Nowa Książka” 1938, nr 5.

$76 \mathrm{Z}$ mód humanistyki lat pięćdziesiątych-siedemdziesiątych XX wieku (i pomijając dyskurs marksistowski) idiolekt strukturalizmu, wbrew podręcznikowym uproszczeniom, nigdy nie był monolitem, zaś inspiracje cybernetyką tudzież nadzieje na matematyzację badań humanistycznych szybko wygasły.

77 W tym zarówno języka publikacji samego Romana Witolda, kształtowanego podczas seminariów spójnego idiolektu fenomenologicznego, jak i języka, w którym piszemy o Ingardenie oraz jego koncepcjach. 
Ingarden R., Spór o istnienie świata, t. 1, przygotowała i partie tekstu przetłumaczyła D. Gierulanka, Warszawa 1987.

Ingarden R., Spór o istnienie świata, t. 2, cz. 2, przygotowała i partie tekstu przetłumaczyła D. Gierulanka, Warszawa 1987.

Ingarden R., Z badań nad filozofią wspótczesną, Warszawa 1963.

Ingarden R., Z teorii jezyka i filozoficznych podstaw logiki, Warszawa 1972.

Ingarden R.S., Roman Witold Ingarden. Życie filozofa w okresie toruńskim (19211926), Toruń 2000.

Ingarden R.W., Dziennik osobisty (wybór), oprac. R. Kuliniak, M. Pandura, „Konteksty Kultury" 2021, t. 18, z. 1.

Korespondencja Izydory Dambskiej z Romanem Witoldem Ingardenem, oprac., red. R. Kuliniak, D. Leszczyna, M. Pandura, Ł. Ratajczak, Kęty 2018.

Korespondencja Romana Witolda Ingardena. Z dziejów „Studia Philosophica. Commentarii Societatis Philosophicae Polonorum”, oprac., red. R. Kuliniak, D. Leszczyna, M. Pandura, Ł. Ratajczak, Kęty 2018.

Korespondencja Romana Witolda Ingardena z Kazimierzem Twardowskim, oprac., red. R. Kuliniak, D. Leszczyna, M. Pandura, Kęty 2016.

Korespondencja Romana Witolda Ingardena z Wtadystawem Tatarkiewiczem; oprac., red., wstęp, wprowadzenie R. Kuliniak, M. Pandura, Kęty 2021

Korespondencja Wincentego Lutostawskiego z Kazimierzem Twardowskim. Lata 1893-1936, oprac., red. R. Kuliniak, D. Leszczyna, M. Pandura, Ł. Ratajczak, Kęty 2017.

Korespondencja Wtadystawa Werybyz Kazimierzem Twardowskim, oprac., red. R. Kuliniak, D. Leszczyna, M. Pandura, Ł. Ratajczak, Kęty 2017.

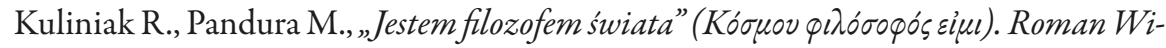
told Ingarden (1893-1970). Część pierwsza: lata 1893-1938, Kęty 2019.

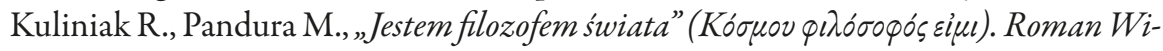
told Ingarden (1893-1970). Część druga: lata 1939-1970, Kęty 2020.

Kuliniak R., Pandura M., Lwowskie Seminarium Arystotelesowskie Romana Witolda Ingardena z lat 1937-1938, Kęty 2020.

Kuliniak R., Pandura M., Poeta sam na sam z soba - dziennik osobisty Romana Witolda Ingardena, „Konteksty Kultury” 2021, t. 18, z. 1.

Kuliniak R., Pandura M., Roman Witold Ingarden we Wroctawiu. Zapomniana historia Uniwersytetu Wroctawskiego z 1945 roku, Kęty 2020.

Kuliniak R., Pandura M., Ratajczak Ł., Filozofia po ciemnej stronie mocy, cz. 1-2, Kęty 2018-2019.

Lwowskie czwartki Romana W. Ingardena 1934-1937. W kregu problemów estetyki ifflozofii literatury, oprac. D. Ulicka, Warszawa 2020.

Majewska Z., Ksiązeczka o Ingardenie. Szkic biograficzny, Lublin 1995.

Ogrodnik B., Ingarden, Warszawa 2000.

Roman Ingarden and His Times, red. D. Czakon, A. Michna, L. Sosnowski, Kraków 2020. Roman Ingarden. Filozof ifotograf/ Philosopher and Photographer, red. M.A. Potocka, Kraków 2020. 
„Ruch Filozoficzny” 2020, t. LXXVI, nr 1: W pięídziesiata rocznicéśmierci Profesora Romana Witolda Ingardena.

Sobota D.R., Narodziny fenomenologii z duch a pytania. Johannes Daubert ifenomenologiczny rozruch, Warszawa 2017.

Spiegelberg H. [współpraca K. Schumann], The Phenomenological Movement: A Historical Introduction, The Hague 1982.

Spotkania. Roman Ingarden we wspomnieniach, red. L. Sosnowski, Kraków 2020.

Tatarkiewicz W., Dzienniki. Tom 1. Lata 1944-1960, oprac. R. Kuliniak, D. Leszczyna, M. Pandura, Ł. Ratajczak, red. M. Urbańska-Bożek, Kęty 2019.

Twardowski K., Lwowskie wyktady akademickie, t. 1-2, oprac., red. R. Kuliniak, D. Leszczyna, M. Pandura, Ł. Ratajczak, Kęty 2018-2020.

Ulicka D., Stowa i ludzie. 10 szkiców z antropologii filologicznej, Warszawa 2013.

Wiek teorii. Sto lat nowoczesnego literaturoznawstwa polskiego, red. D. Ulicka, Warszawa 2000. 